\title{
MOTIVASI DAN KEPEMIMPINAN
}

Makalah ini disusun guna memenuhi tugas mata kuliah "PENGANTAR MANAJEMEN"

Dosen Pembimbing :

Dra. Hj. Nuraeni Gani.M.M

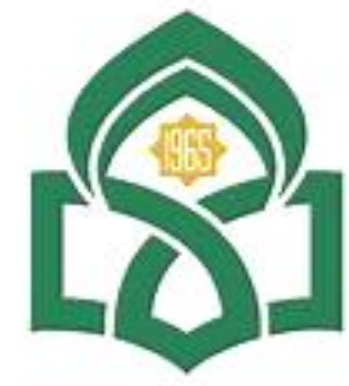

UNIVERSITAS ISLAM NEOERI

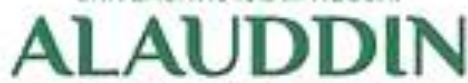

$M A K A$ S S A R

DISUSUN OLEH :

NURUL UYUN

90500121016

PRODI PERBANKAN SYARIAH

FAKULTAS EKONOMI DAN BISNIS ISLAM

UNIVERSITAS ISLAM NEGERI MAKASSAR

2021 M / 1443 


\section{KATA PENGANTAR}

Alhamdulillah, segala puja dan puji syukur kehadirat Allah swt. Yang telah memberikan kami kesehatan serta kesempatan sehingga kami bisa mengerjakan serta menyelesaikan makalah ini.

Shalawat serta salam semoga selalu terlimpah kepada Rasulullah Muhammad saw. yang telah menyampaikan risalah wahyu sebagai petunjuk untuk meraih kebahagiaan di dunia dan akhirat kelak. Selanjutnya, terima kasih kami ucapkan kepada Ibu Dra. Hj. Nuraeni Gani.M.M selaku dosen pembimbing mata kuliah “PENGANTAR MANAJEMEN" ini, atas bimbingannya. Alhamdulillah kami dapat menyelesaikan makalah ini meskipun masih banyak terdapat kekurangan di dalamnya. Karena itu, kritik dan saran sangat kami harapkan dalam upaya penyempurnaan makalah ini. Akhirnya, semoga makalah ini dapat memberi manfaat kepada kita semua. Amin.

Makassar, 9 November 2021

Nurul Uyun 


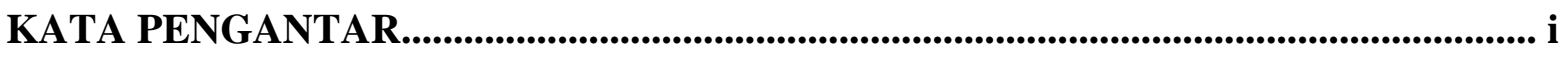

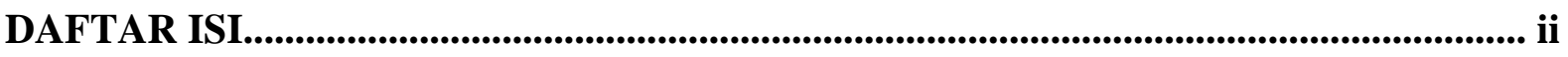

BAB I PENDAHULUAN
A. Latar Belakang.
B. RumusanMasalah 1 2

\section{BAB II PEMBAHASAN}

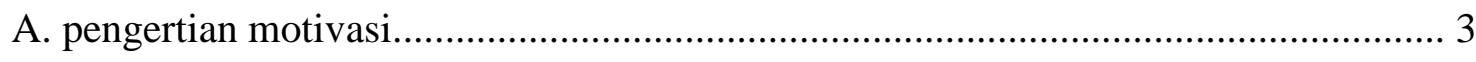

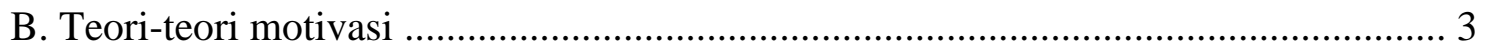

C. dalil al-quran dan hadist tentang motivasi........................................................ 4

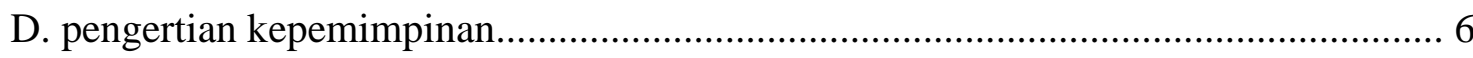

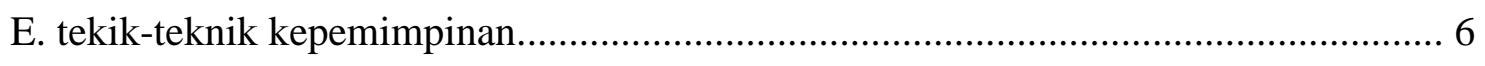

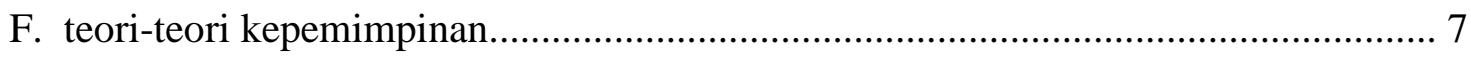

G. Apa saja dalil al-quran dan hadist tentang kepemimpinan.................................. 8

\section{BAB III PENUTUP}

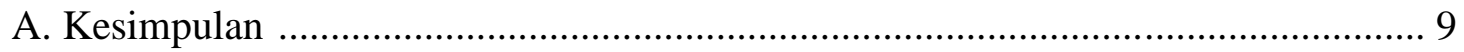

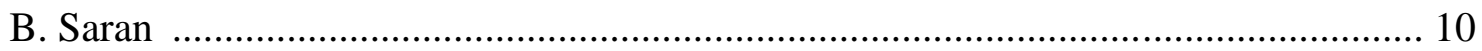

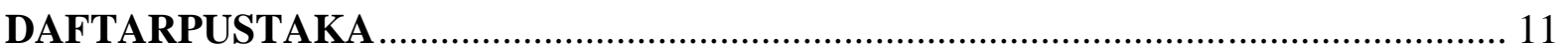





\section{BAB I \\ PENDAHULUAN}

A. Latar Belakang

Manusia adalah mahluk social yang tidak dapat hidup sendiri. Dalam hidup, manusia selalu berinteraksi dengan sesama serta lingkungan. Manusia hidup berkelompok baik dalam kelompok besar maupun berkelompok kecil.

Manusia adalah mahluk tuhan yang paling tinggi dibandingkan mahluk tuhan yang lainnya. Manusia dianugrahi kemampuan untuk berfikir, kemampuan untuk memilah mana ynag baik dan mana yang buruk. Dengan kelebihan itulah manusia seharusnya mampu mengelola lingkungan dengan baik.

Tidak hanya lingkungan yang perlu dikelola dengan baik, kehidupan social manusiapun perlu dikelola dengan baik. Untuk itulah dibutuhkan sumber daya manusia yang berkualitas. Sumber daya yang berjiwa pemimpin, paling tidak untuk memimpin untuk dirinya sendiri. Dengan berjiwa pemimpin manusia akan dapat mengelola diri, kelompok dan lingkungan dengan baik. Khususnya dalam penanggulangan maslah yang relative pelik dan sulit. Disinilah dituntut kerifan seseorang pemimpin dalam mengambil keputusan agar masalah dapat terselesaikan dengan baik.

Pemimpin dapat mempengaruhi moral, kepuasan kerja, keamanan, kualitas kehidupan kerja dan terutama tingkat prestasi suatu organisasi. Kemampuan dan ketrampilan kepemimpinan dan motovasi dalam pengarahan adalah factor penting efektivitas manajer. Bila organisasi dapat mengidentifikasikan kualitaskualitas yang berhubungan dengan kepemimpinan, kemampuan untuk menyeleksi pemimpin-pemimpin yang efektif akan meningkat, bila organisasi dapat mengidentifikasikan perilaku dan teknik-teknik kepemimpinan efektif organisasi, berbagai perilaku dan teknik tersebut akan dapat dipelajari.

Penilaian prestasi kerja (performance appraisal) adalah proses melalui mana organisasiorganisasi mengevaluasi atau menilai prestasi kerja pegawai. Kegiatan ini dapat memperbaiki keputusan-keputusan personalia danmemberikan umpan balik kepada para pegawai tentang pelaksanaan kerja mereka. Kegunaan-kegunaan penilaian prestasi kerja dapat dirinci sebagai berikut, perbaikan prestasi kerja, penyesuaian-penyesuaian kompensasi, keputusan-keputusan penempatan, kebutuhan latihan dan pengembangan, perencanaan dan pengembangan karier, penyimpangan-penyimpangan proses staffing, ketidakakuratan informasional, kesalahan desain pekerjaan, kesempatan kerja yang adil dan tantangan-tantangan eksternal (Handoko, 1997).Disamping faktor kepemimpinan, faktor motivasi yang akan mempengaruhi kinerja pegawai yang dimiliki seseorang adalah merupakan potensi, dimana seseorang belum tentu bersedia untuk mengerahkan segenap potensi yang dimilikinya untuk mencapai hasil yang optimal.

Analisis ilmiah tentang kepemimpinan berangkatbdari pemusatan perhatian pemimpin itu sendiri. Theory sifat berkembang, pertama kali di Yunani Kuno dan Romawi yang beranggapan bahwa pemimpin itu dilahirkan, bukan diciptakan yang kemudian theory ini dikenal dengan " The Greatma Theory'. Dalam perkembangannya, theory ini mendapat pengaruh dari aliran perilaku pemikir psikolosi yang berpandangan bahwa sifat sifat 
kepemimpinan tidak seluruhnya dilahirkan akan tetapi juga dapat dicapai melalui pendidikan dan pengalaman.

B. Rumusan Masalah

Dari latar belakang masalah yang penulis uraikan, banyak permasalahan tsb antara lain :

1. Apa pengertian motivasi

2. Apa Teori-teori motivasi?

3. Apa saja dalil al-quran dan hadist tentang motivasi?

4. Apa pengertian kepemimpinan?

5. Apa tekik-teknik kepemimpinan?

6. Apa teori-teori kepemimpinan?

7. Apa saja dalil al-quran dan hadist tentang kepemimpina? 


\section{BAB II \\ PEMBAHASAN}

A. Pengertian Motivasi

Motivasi adalah proses pemberian motif (penggerak) epada karyawan atau anggota untuk dapat bekerja sedemiian rupa sehingga tujun organisasi secara efisien dapat tercapai. Jadi didalam memberikan motivasi, menejer harus mempengaruhi sikap bawahan agar merea bersedia untuk menjalankan tugas-tugas yang selaras dengan tujuan organisasi. Faktor-fator penting yang mempengarui motivasi adalah:

1. Kebutuhan pribadi

2. Tujuan dan persepsi individu atau kelompok

3. Cara untuk mewujidkan kebutuhan, tujuan dan persepsi.

Apabila para pekerja menyukai peerjaan merek, mengagap bahwa tugas mereka penuh dengan tantangan da mereka menyukai lingkungan kerja secara umum maka biasanya mereka akan berusaha secara maksimal untuk melaksanakan pekeraan mereka dengan semangat da berdedikasi.

Dalam hal ini terdapat 2 motivasi yaitu :

a. Motivasi Positif

Merupakan proses untuk mempengaruhi orang lain dengan cara memberika penambahan tingkat kepuasan tertentu, misalnya dengan memberia promosi, tambahan penghasilan, menciptaan kondisi kerja yang nyaman dan lain sebagainya.

b. Motivasi Negatif

Adalah proses untuk mempengaruhi orang lain dengan cara menakut-nakuti atau mendorong seseorang untuk melaukan sesuatu secara terpaksa. Misalnya memberi gambaran akan diturunkan pangkatya, dipotong gajinya ataupun dipecat dari jabatannya.

\section{B. Teori-teori Motivasi}

1. Teori Motivasi Kebutuhan (Abraham H. Maslow)

Menyatakan bahwa manusia dimotivasi untuk memuaskan sejumlah kebutuhan yang melekat pada diri setiap manusia yang cenderung bersifat bawaan. Adapun kebutuhan itu adalah:
a. Kebutuhan fisik (physiological needs)
b. Kebutuhan akan keamanan/keselamatan (safety/security needs)
c. Kebutuhan untuk berkelompok (sosial needs)
d. Kebutuhan akan harg diri/penghormatan (egoistic needs)
e. Kebutuhan akan pengakuan diri dan pengembangan diri (self realization needs) 


\section{Teori Motivasi Herzberg}

Herzberg menyatakan bahwa ada faktor-faktor tertentu di tempat kerja yang menyebabkan kepuasan kerja, sementara pada bagian lain adapula ketidak puasan. Dengan kata lain kepuasa dan ketidak puasan berhubungan satu sama lain.

Faktor-faktor tertentu ditempat kerja tersebut didevinisikan sebagai hygiene factors (faktor kesehatan) dan motivation factors (faktor pemuas). Dua faktor ini oleh Herzberg dialamatkan kepada faktor intrinsik dan faktor ekstrinsik, dimana faktor intrinsik adalah faktor yang mendorong karyawan termotivasi yaitu daya dorong yang timbul dari dalam diri masingmasing orang. Dan faktor ekstrinsik yaitu daya dorong yang datang dari luar diri seseorang, terutama dari organisasi tempat bekerja.

3. Teori Motivasi McClelland

Menyatakan kebutuhan manusia ada 3 yaitu:

a. Kebutuhan berprestasi (needs for acbievement) yaitu keiginan untuk melakukan sesuatu lebih baik dibandingkan sebelumnya.

b. Kebutuhan untuk berkuasa (needs for power) yaitu kebutuhan untuk lebih kuat, lebih berpengaruh terhadap orang lain.

c. Kebutuha afiliasi (needs for affiliation) yaitu kebutuhan untuk disukai, memelihara atau mengembangkan persahabatan dengan orang lain.

\section{Dalil Al-Quran dan Hadist tentang Motivasi}

1. QS. Al-Baqarah: 216

Yang Artinya: "Diwajibkan atas kamu berperang, padahal berperang itu adalah sesuatu yang kamu benci. boleh jadi kamu membenci sesuatu, padahal ia amat baik bagimu, dan boleh jadi (pula) kamu menyukai sesuatu, padahal ia amat buruk bagimu Allah mengetahui, sedangkan kamu tidak mengetahui.

2. QS. Al-Baqarah: 286

Yang Artinya: "Allah tidak membebani seseorang melainkan sesuai dengan kesanggupannya. ia mendapat pahala (dai kebajikan) yang diusahakannya dan ia mendapat siksa (dari kejahatan) yang dikerjakannya. (Mereka berdoa): "Ya Tuhan kami, janganlah Engkau hukum kami jika kami lupa atau kami tersalah. Ya Tuhan kami, jangnlah engkau bebankan kepada kami beban yang berat sebagaimana engkau bebankan orang-orang sebelum kami. Ya Tuhan kami, janganlah engkau pikulkan kepada kami apa yang tak sanggup kami memikulnya. Beri maaflah kami, dan ampunilah kami dan rahmatilah kami. Engkau Penolong kami, maka tolonglah kami terhadap kaum yang kafir."

\section{QS. Ar-Ra'd: 11}

Yang Artinya: "Bagi manusia ada malaikat-malaikat yang selalu mengikutinya bergiliran, di muka dan di belakangnya, mereka menjaganya atas perintah Allah. sesungguhnya Allah tidak mengubah keadaan suatu kaum sehingga mereka mengubah keadaan yang ada pada diri mereka sendiri. dan apabila Allah menghendaki keburukan terhadap suatu kaum, maka tak ada yang dapat menolaknya, dan sekali-kali tak ada pelindung bagi mereka selain Dia." 


\section{Pengertian Kepemimpinan}

Kepemimpinan merupakan kemampuan yang dimiliki oleh seseorang untuk mempengaruhi orang-orng agar bekerja untu mencapai tujuan dan sasarannya. Kepemimpinan menurut para ahli yaitu:

1. Menurut Bass dan Bass (2011), epemimpinan adalah interaksi dua orang atau lebih dalam suatu kelompok tersetruktur atau struktur orang terhadap situasi persepsi dan harapan anggota.

2. Yuki (2010), kepemimpinan adlah proses mempengaruhi orang lain untuk memahami dan menyetujui kebutuhan yang harus dipenuhi dan cara melakukannya, serta proses memfasilitasi individu dan kelompok berusaha mencapai tujuan yang sama.

3. Northouse (2009), kepemimpinan adalah suatu sifat, sebuah kemampuan, sebuah ketrampilan, suatu perilaku dan suatu hubungan.

4. Stogdill (1974), kepemimpinan adalah fous dari proses kelompok, peenerimaan kepribadian seseorang, seni memengarui perilaku, alat utuk memengaruhi perilaku, suatu tindakan perilaku, bentuk dan ajakan, bentuk dari relasi yang kuat, alat untuk mencapai tujuan, akibat dari interaksi, peranan yang diferensial dan pembuat struktur.

Kepemimpinan adalah proses pengarahan yang dapat memotivasi orang lain untuk bekerja kearah pencapaian tujuan tertentu. Adi dalam kepemimpinan ini melibatkan kemampuan seseorang untuk mempengaruhi orang lain. Disini motivasi harus dapat diterima oleh orang lain dan menjadi pendorong untuk mencapai tujuan yang telah ditentukan

\section{E. Teknik-Teknik Kepemimpinan}

1. Fungsi-fungsi kepemimpinan

Fungsi kepemimpinan adalah untuk menjalankan berbagai pekerjaan yang telah direncanaan dalam suatu organisasi. Dengan demikian kepemimpinan yang efektif adalah ketika pemimpin mampu mempengaruhi orang-orang untuk dapat melakukan tugas-tugas yang telah dipercayakan oleh mereka.

Adapun fungsi-fungsi yang terkait dengan hubungan sosial atau pemeliharaan kelompo memfouska fungsi kepemimpinan dalam upaya untuk senantiasa memelihara esatuan dintara sesama pekerja, dengan demikian pemimpin yang efektif adalah ketika emimpin tersebut mampu berkomunikasi dengan baik dengan tim kerja, mengaja mereka untuk senantias memelihara dan saling pengertian sehingga tim kerja yang ada senantiasa terpelihara dengan baik.

\section{Ciri Kepemimpinan}

Istilah kepemimpinan yang diukiskan oleh chung dan Megginsion sebagai "kesanggupan mempengaruhi perilaku orang lain dalam suatu arah tertentu". Pada dasarnya usaha untuk mempengaruhi perilaku adalah unsur pook kepemimpinan.[2]

Ciri pemimpin menurut islam:

a. Setia 

b. Terikat pada tujuan
c. Menjunjung tinggi syariat dan akhlak islam
d. Memegang teguh amanah
e. Tidak sombong
f. Disiplin, konsisten dan konsekuen[3]

Syarat yang sering tampak dalam diri pemimpin:

1. Kesanggupan utuk memecahkan persoalan seara kreatif

2. Kesanggupan berkomunikasi dengan mendengarkan

3. Hasrat yang kuat untuk mecapai sesuatu

4. Banyak berkepentingan dan sosiabilitas

5. Sikap-siap positif dan tulus terhadap para bawahan

6. Kepercayaan diri

7. Kegairahan

8. Kedislipinan

9. Tata rama

10. kemantapan emosional

Syarat seorang pemimpin yani merasa puas dengan selesainya pekerjaan dengan memenuhi kebutuhan kelompoknya. Pemimpin itu mempunyai kemampuan untuk memutuskan, tindakan apa yang paling baik untuk mencapai tujuan kelompo itu.

Jenis kepemimpinan yang digunakan harus berbeda-beda sesuai situasi kerja yaitu, kepemimpinan yang sama belum tentu sama efektifnya dalam segala keadaan. Karena pemimpin yang khas itu terlihat dalam situasi yang berbeda-beda maka haruslah seorang pemimpin memimpin sesuatu yang dianggp sulit oleh banyak pemimpin.

\section{Gaya Kepemimpinan}

Gaya kepemimpinan akan ditentukan oleh berbagai faktor, yaitu dari segi latar belakang, pengetahuan, nilai dan pengalaman dari pemimpin tersebut. Selain keempat faktor tersebut karakteristik dari bawahan atau orang-orang yang dipimpin juga perlu untuk dipertimbangkan sebelum memutusan gaya kepemimpinan apa yang seharusnya digunakan. Pada dasarnya gaya kepemimpinan bersifat situasional. Contoh, missal ketika kegiatan perusahaan berjalan normal, maka pemimpin perlu mengembangkan gaya kepemimpinan yang bersifat demokratis yang menyeimbangkan antara orientasi kepada orang-orang dan orientasi kepada peerjaan. Manajer perlu meluangkan waktu untuk mendengarkan masukan dari bawahan dan memahami keinginan-keinginan mereka. 


\section{a. Model kepemimpinan situasional}

Paul Hersey dan Knneth H Blanchard beranggapan bahwa model ini membahas bahwa para manajer perlu menyesuaikan gaya kepemimpinan mereka sebagai respon terhadap berbagai karakter dari orang-orang bawahannya seperti harapan bekerja, pengalaman, keahlian dan kesanggupan dalam menerima tanggung jawab. Model ini dibagi empat kuadran menurut situasi yang dihadapi yang dikaitkan dengan tinggi rendahnya kecenderungan kepada pekerjaan (task behavior) dan tinggi rendahnya kecenderungan kepada orang-orang (relatiship behavior).

Kuadran pertama (high task and low relationship) dimana situasi yang dihadapi adalah adanya tuntutan pekerjaan yang tinggi dan rendah terhadap orang-orang yang relasi, maka pemimpin berorientasi pada pekerjaan yang tinggi lebih dibutuhkan.

Kuadran kedua (high task and high relationship) dimana kondisi yang dihadapi memerlukan perhatian yang tiggi terhadap pekerjaan sekaligus orang-orang, gaya kepemimpinan demokratis dan berorientasi kepada kemajuan dan perubahan sangat diperlukan.

Kuadran tiga (high relationship and low task) pekerjaan memiliki karakteristik tim kerja yang baik dan mereka termotivasi dengan baik untuk berada dalam organisasi akan tetapi belum banyak diarahkan pada pekerjaan yang memberikan tantangan kepada mereka sehingga pada orientasi pada pekerjaannya masih rendah.

Model Vroom-Yetton-Jago (VYT)

Modelin diperkenalkan pada tahun 1973 dan disempurnakan pada tahun 1988 oleh Vroom dan Arthur G. Jago. Model ini memfokuskan tingkat partisipasi bawahan dalam pengambilan keputusan.[5]

\section{F. Teori-Teori Kepemimpinan}

1. Teori sifat

Teori ini sering disebut teori "The Great Man" yang menyatakan bahwa, seorang yang dilahirkan menjadi emimpin ia akan menjadi pemimpin apakah ia mempunyai sifat seorang pemimpin. Apabila ia tidak membawa sifat tersebut, maka ia akan berusaha memperolehnya dengan cara mempelajari sejarah pemimpin- pemimpin besar untuk menemukan ciri yang dimiliki mereka, misalnya Napoleon, Mahatma Gandhi dan lain-lain.

\section{Teori kelompok}

Anggapan teori ini bahwa supaya kelompok bisa mencapai tujuannya maka harus terdapat suatu pertukaran yang positif diantara pemimpin dan pengikutnya. Disini dapat dijelaskan pula bahwa para bawahan, atau anggota dapat mempengaruhi pemimpin dengan perilakunnya , sebanyak pemimpin beserta perilakunya mempengaruhi bawahannya. Juga dapat dikatakan, jika para bawahan tidak melaksankan pekerjaan secara baik, maka pemimpin cenderung menekannkan pada struktur pengambilan inisiatif (perilaku tegas). Tetapi ketika para bawahan dapat melaksanakan pekerjaan dengan baik, maka pemimpin menaikkan penekanannya pada pemberian perhatian.

3. Teori situasional dan model kontijensi 
Fred Fiedler mengembangkan suatu teknik untuk mengkur gaya kepemimpinan yang dikenal dengan "A Theory of Leardeship Effectiveness". Model kepemimpinan kontijensi berisi tentang hubungan antar gaya kepemimpinan dengan situasi yang menyenangkan. Adapun situasi yang menyenagkan itu diterangkan oleh Fedler dalam hubungannya dengan dimensidimensi empiris sebagai berikut:

a. Hubungan pemimpin anggota (pemimpin diterima oleh para anggotannya)

b. Derajat dari struktur tugas (tugas ditentukan secara jelas)

c. Posisi kekuasaan pemimpin yang dicapai lewat wewenang formal.

Manakala terjadi hal yang sebaliknya, maka menurut Fedler akan tercipta situasi yang tidak menyenangkan bagi pemimpin.

4. Teori jalan kecil- tujuan (Path-goal Theory)

Teori ini menganalisis dampak kepemimpinan terhadap motivasi bawahan kepuasan dan pelaksanaan kerja.

Martin Evans dan Robert House memasukkan empat tipe gaya kepemimpinan yaitu:
a. Kepemimpinan Derektif
b. Kepemimpinan Suportif
c. Kepemimpinan Partisipatif
d. Kepemimpinan yang berorientasi pada Prestasi

Seorang pemimpin yang baik adalah seseorang yang tidak melaksanakan sendiri kegiatan atau tindakan yang bersifat operasional, tetapi mengambil keputusan, menentukan kebijakan dan menggerakkan orang lain untuk melaksanakan keputusan yang telah diambil sesuai dengan kebijakan yang telah digariskan.

\section{G. Dalil Al-quran dan Hadis tentang Kepemimpinan}

Berikut ini merupakan Al-Qur'an yang menunjukkan dengan jelas larangan memilih pemimpin Non Muslim bagi wilayah yang mayoritas penduduk Muslim.

1. QS. Ali Imron $\{3\}: 28$.

Yang Artinya: "Janganlah orang-orang mukmin mengambil orang-orang kafir menjadi WALI pemimpin, teman setia atau pelindung. dengan meninggalkan orang-orang mukmin, barang siapa berbuat demikian, niscaya lepaslah ia dari golongan Allah, kecuali kerena (siasat) memelihara diri dari sesuatu yang ditakuti dari mereka. dan Allah memperingartkan kamu terhadap diri (siksa)-Nya, dan hanya kepada Allah kamu kembali."

2. QS. An-Nisa' $\{4\}: 144$

Yang Artinya: "Hai orang-orang yang beriman janganlah kamu mengambil orangorang kafir menadi WALI (pemimpin) dengan meniggalkan orang-orang mukmin, Apakah kami ingin mengadakan alasan yang nyata bagi Allah (untuk menyiksamu). 
3. QS. Al-Ma'idah\{5\}:57. Yang Artinya: "Hai orangorang yang beriman, janganlah kamu mengambil orang-orang yang membuat agamamu jadi buah ejekan dan permainan, (yaitu) diantara orang-orang yang telah diberi kitab sebelummu, dan orang-orang yang kafir (orangorag musyrik) sebagai WALI (pemimpinmu). Dan bertakwalah kepada Allah jika kamu betulbetul orang-orang yang beriman."

\section{BAB III}

PENUTUP

\section{A. Kesimpulan}

Kepemimpinan dan Motivasi

Kepemimpinan dan motivasi merupakan dua hal yang berbeda, meski memiliki tautan dalam konteks kerja dan interaksi antar-manusia organisasional. Keith Davis mengemukakan bahwa tanpa kepemimpinan, organisasi hanya merupakan kelompok manusia yang kacau, tidak teratur, dan tidak akan dapat melahirkan perilaku bertujuan. Kepemimpinan adalah faktor manusiawi yang mengikat suatu kelompok bersama dan memberinya motivasi menuju tujuan-tujuan tertentu, baik dalam jangka pendek maupun jangka panjang. Ini berarti antara kepemimpinan dengan motivasi memiliki ikatan yang kuat.

Dari rumusan tadi, keterkaitan antara kepemimpinan dengan motivasi dapat dianalisis sebagai berikut:

1. Tanpa kepemimpinan, organisasi tidak lain adalah sekelompok manusia yang kacau.

Manusia organisasional, baik dalam kapasitas masing-masing dan terutama sebagai anggota kelompok, dituntut dapat memacu upaya pencapaian tujuan organisasi yang sekaligus bagian dari tujuan dirinya. Kehadiran pemimpin memungkinkan manusia organisasional dimotivasi untuk dapat bekerja secara efektif dan efisien. Kelompok dengan sistem yang kurang padu dapat menurunkan produktifitas organisasi. Atas dasar itu, manusia organisasi perlu diarahkan dan dimotivasi oleh pemimpinnya agar dapat bekerja secara efektif dan efisien, dengan akuntabilitas tertentu.

2. Kepemimpinan berkaitan dengan kepengikutan.

Kepengikutan (followership) adalah bagian yang paling dalam usaha melahirkan perilaku organisasi yang sesungguhnya. Bahkan ada yang mengatakan bahwa pada hakikatnya kepemimpinan adalah kepengikutan (leadership is follower). Istilah ini adakalanya diberi makna luas, bahwa pemimpin yang baik dihasilkan dari pengikut yang baik. Manusia pengikut di sini tidak dapat dipersepsi sebagai robot, Melainkan mereka adalah manusia biasa 
yang memiliki perasaan, kebutuhan, harapan, dan aspek manusiawi lainnya. Tanpa pemahaman terhadap aspek-aspek manusiawi yang dipimpin, kepemimpinan akan gagal.

3. Kepemimpinan mengandung arti kemampuan memotivasi.

Kompetensi bawahan antara lain tercermin dari motivasi kerjanya. Dia bekerja disebabkan oleh dua kemungkinan, yaitu benar-benar terpanggil untuk berbuat atau karena diharuskan untuk melakukan tugas-tugas itu. Banyak faktor yang mempengaruhi motivasi manusia dalam bekerja, antara lain bahwa manusia mempunyai seperangkat kebutuhan, mulai dari kebutuhan yang paling dasar (biologis) sampai kepada taraf kebutuhan paling tinggi, aktualisasi diri. Salah satu faktor yang mempengaruhi motivasi kerja seseorang adalah gaya kepemimpinan. Dengan demikian, kepemimpinan dapat pula berarti kemampuan memberi motivasi kepada bawahan.

Motivasi adalah perpaduan antara keinginan dan energi untuk mencapai tujuan tertentu. Memengaruhi motivasi seseorang berarti membuat orang tersebut melakukan apa yang kita inginkan. Karena fungsi utama dari kepemimpinan adalah untuk memimpin, maka kemampuan untuk memengaruhi orang adalah hal yang penting.

Rahasia utama kepemimpinan adalah kekuatan terbesar seorang pemimpin bukan dari kekuasaannya, bukan kecerdasannya, tapi dari kekuatan pribadinya. Seorang pemimpin sejati sealalu bekerja keras memperbaiki dirinya sebelum sibuk memperbaiki orang lain. Pemimpin bukan sekedar gelar atau jabatan yang diberikan dari luar melainkan sesuatu yang tumbuh dan berkembang dari dalam diri sesorang. Kepemimpinan lahir dari sesorang. Kepemimpinan lahir dari proses internal. 


\section{DAFTAR PUSTAKA}

Konssen, Stan. 1993. Aspek Manusia Dalam Organisasi Edisi Ketiga. Jakarta: Erlangga. Rivai, Vethzal. Arviyan Arifin. 2009. Islamic Leadership. Jakarta: PT Bumi Aksara.

Sumarni, Murti. John Soeprihanto. 2003. Pengantar Bisnis. Yogyakarta: Liberty.

Tisnawati, Erni Sule. Kurniawan Saefullah. 2005. Pengantar Manajemen Edisi I. Jakarta: Prenada Media Group. 